\title{
“ҒАРОЙИБ УС-СИҒАР” ДЕВОНИДАГИ ҒАЗАЛЛАРДА ТАЖНИС САНЪАТИ Қамаруддин ҚАНИТ
}

Магистрант

Алишер Навоий номидаги Тошкент давлат ўзбек тили ва адабиёти университети

Тошкент, Ўзбекистон

\section{ПОЭТИЧЕСКАЯ ФИГУРА ТАДЖНИС В ГАЗЕЛЯХ ДИВАНА «ЧУДЕСА ДЕТСТВА» АЛИШЕРА НАВОИ \\ Камаруддин КАНИТ}

Магистрант

Ташкентский государственный университет узбекского языка и литературы имени Алишера Навои

Ташкент, Узбекистан

\section{THE POETIC FIGURE OF TAJNIS IN THE GAZELLES OF THE POETRY BOOK DIVAN “MIRACLES OF CHILDHOOD” BY ALISHER NAVOI \\ Qamaruddin QANIT}

Master's student

Tashkent State University of Uzbek Language and Literature named after Alisher Navoi Tashkent, Uzbekistan qamaruddinqanet@gmail.com

УДК 821.512.133Навоий7“ҒҒаройиб уссиғар"

For citation (иқтибос келтириш учун): Қанит Қ. “Ғаройиб ус-сиғар” девонидаги ғазалларда тажнис санъати// Ўзбекистонда хорижий тиллар. - 2021. — № 6 (41). — Б. 215-228.

\section{https://doi.org/10.36078/1644604930}

Received: October 15, 2021

Accepted: December 17, 2021

Published: December 20, 2021

Copyright (C 2021 by author(s) and Scientific Research Publishing Inc.

This work is licensed under the Creative Commons Attribution International License (CC BY 4.0)

http://creativecommons.org/licenses/by/4.0/

\section{Open Access}

Аннотация. Ушбу мақолада шеърий санъатлардан бири тажнис хақида бахс юритилган. Муаллиф ушбу бадиий санъатга мумтоз адабиётшуносликдаги фикрлардан келиб чиқиб бахо берар экан, уларга ўз муносабатини билдиради, муайян хулосаларга келади. Бу масала бўйича ўзбек шеършунослигида мавжуд фикрлар билан бирга эронлик, афғонистонлик олимларнинг тадқиқотларига эътиборни қаратади, уларнинг тажнис сохасида, умуман шеърий санъатлар билан боғлиқ ишларини амалиётга татбиқ этади. Улар томонидан берилган таърифларга ўз муносабатини билдиради. Шеърий санъатлар ичида тажниснинг ўрни алохида. Тажнис шеьр бадииятини кучайтирадиган, сўз уй̆инларини хосил қиладиган, сўздаги маънонинг хилма-хил товланишларини кўрсатиб берадиган бадиий санъатдир. Муаллиф тажниснинг айнан шу сифатларини назарда тутиб, ушбу санъат ва унинг турлари хақидаги назарий фикрларини Алишер Навоий ғазаллари мисолида асослаб берган. Шоирнинг "Ғаройиб ус-сиғар" девонидаги ғазалларда истифода этилган тажнис санъати турларининг деярли барчасини ўрганиб чиққан. Тажниснинг ўндан ортиқ турига мисоллар келтириб, уларнинг ғазаллардаги ўрнини аниқлаган, уларни тахлил қилган. "Ғаройиб ус-сиғар" девонидаги ғазаллардаги тажнис санъатига асосланган байтлар, умуман ғазаллар билан боғлиқ статистик маълумотларни тақдим этган. Калит сўзлар: бадиий санъат; тажнис; тажнис турлари; ғазал; байт; сўз ўйини; маъно товланиши.

Аннотация. В статье рассматривается поэтическая фигура таджнис, которая широко используется в восточной 
(арабской, персидской, тюркской) классической поэзии. Исходя из представлений классического литературоведения, автор оценивает эту поэтическую фигуру в классическом тексте, выражает свое отношение к ней, приходит к определенным выводам. Наряду с существующими представлениями в узбекской поэзии по данному вопросу, автор обращает внимание на исследования иранских и афганских ученых, их работы в области таджниса, и в целом изыскания, связанные с поэтическими фигурами. Среди поэтических фигур восточной поэзии особое место занимает таджнис. Таджнис - поэтическая фигура, которая совершенствует художественную окраску газели, формирует словесные игры в бейте, показывает различные варианты значения слова. Автор, имея в виду именно эти качества таджниса, обосновывает свои теоретические взгляды к этой поэтической фигуре и ее видам на примере газелей Алишера Навои. Он исследует почти все виды таджниса, представленные в газелях дивана Навои "Гаройиб ус-сигар" («Чудеса детства»). Иллюстрирует около десяти видов таджниса, определяет их место в газелях, анализирует их. Также автор приводит статистические данные о бейтах газелей в данном диване, где применяется поэтическая фигура таджнис.

Ключевые слова: поэтическая фгура; таджнис; виды таджниса; газель; бейт; игра слов; семантика.

Abstract. This article discusses the poetic figure tajnis, widely
used in Eastern (Arabic, Persian, Turkic) classical poetry.
Evaluating this poetic figure in a classical text, based on the ideas
of classical literary criticism, the author expresses his attitude
towards them and comes to certain conclusions. Along with the
existing theories in Uzbek poetry on this issue, the attention is
drawn to the studies of Iranian and Afghan scientists, their work in
the field of tajnis, in general, associated with poetic figures. Tajnis
occupies a special place among the poetic figures of Eastern
poetry. It is a poetic figure that improves the poetic coloring of the
ghazal, forms word games in the bayt, shows the variety of turns of
meaning in the word and different versions of the meaning of the
word. The author, bearing in mind precisely these qualities of
tajnis, substantiates his theoretical views regarding the types of this
poetic figure based on the example of Alisher Navoi's ghazals. He
explores almost all types of tajnis, presented in the gazelles of the
Navoi divan "Garoyib us-sigar" ("Miracles of childhood"). The
examples of about ten types of tajnis are given; their place in the
gazels has been determined. In addition, the author presents
statistical data on the bayts of gazelles in this divan, where the
poetic figure tajnis is used. Keywords: poetic figure; tajnis; types of tajnis; ghazal; bayt; pun; semantics.

Кириш. Тажнис сўзининг луғавий маъноси жинсдошлик демакдир. Адабий истилох сифатида у лафздашликка асосланган сўз санъатидирки, шаклан бир-бирига ўхшаш, маъноси фарқ қилувчи сўзлар ёрдамида хосил бўлади. "Ўзбек адабиёти фарханги”да таърифланишича, тажнис (арабча сўз. - ўхшаш, шаклан ўхшаш, хамжинс, хамшакл) - оғзаки ва ёзма адабиётдаги бадиий санъатлардан... . ... маъно жахатидан хар хил, аммо шакли бир хил ёки шаклан бир-бирига яқин икки сўзни келтириб, улар воситасида 
муайян фикр, лавха ёки тимсолни таъсирчан ифодалаш санъати (htt//uz.m.wikipedia.org) ёки: тажнис - айтиш ва ёзишда бир-бирига мушобих (ўхшаш), бироқ маънода фарқли бўлган сўзларни шеьр ёки насрда келтирилишидан иборат $(10,7)$. “Алишер Навоий” қомусий луғатида тажнис атамасига куйидагича таьриф берилган: “Тажнис (ap. - жинсдош, хамжинс) - байтда шаклан бир хил ёки бир-бирига яқин сўзларни кўллашга асосланган шеърий санъат. Асосан назмда, баъзан насрда хам иситифода этилади" $(1,10)$.

Тажниснинг, туркий халқлар шеьриятидаги туюқ жанри билан ўхшашлик томонлари бор. Аммо тажнис билан туюқ айнан бир нарса бўлмаган, чунки туюқ сўз ўйинига, кўпинча, тажнис қофиясига асосланган тўрт мисрадан иборат бўлган мустақил шеьрий жанр хисобланади. Туюқда жинсдош сўзлар доимо қофияда қўлланилиб, байтдаги қофиядош сўзлар мураттаб ифодаларни англатади. Тажнисда эса, байт ё жумла таркибида тегишли бўлган сўзларнинг хар бири бошқаси билан исталган ўринларда лафздош, шаклдош бўлиши ва уйғунлашиб келиши мумкин. Демак, жинсдошлашиб келган сўзларнинг хусусиятларига асосланиб тажнис турларга бўлинади. Туюқ эса, турларга бўлинмайди. Тажнис лафзий санъатлар қаторига киради. Ушбу бадиий санъат сўзнинг гўзаллигини оширади, ғазалдаги асосий маънонинг ўқувчи ва тингловчига ёқимли етиб боришини таъминлайди, баъзан сўз ўйинига имкон беради. Бу орқали инсонларнинг отифий (хис-туйғулари) ва ички дунёсига самарали таъсир кўрсатади, сўз бойлигини оширади.

Мумтоз шоирлар жинсдош сўзларни турли маъноларда махорат билан кўллаб, чиройли тажнислар яратганлар. Тажнис санъати, адабиёт кўламидан кенгроқ ва аниқроқ йўсинда, Аллохнинг китоби Қуръони карим оятлари ва пайғамбар с.а.в. хадислари таркибида хам учрайди.

Адабиётда тажнисни бадиийликни кучайтириш, сўз ўйинларини хосил қилиш, сўз маъноларининг хилма-хил товланишларини нимойиш қилиш мақсадларида кўллайдилар.

Тажнис санъати, бадиият хақидаги илмнинг мухим мавзуси хисобланади. Бадиият илми, оддий сўзнинг, адабий ва бадиий сўз даражасига кўтарувчи йўл-йўриқлардан таълим беради. Бадиият илми, адабиётшунослик фанларининг бир қисми бўлиб, адабий сўзни (шељр ва насрни) бадиий санъатлар билан безаб, сўзнинг адабий латофатини санъатлар воситасида орттирилгани хақида таълимот берувчи фандир. Гарчи шеърнинг таъсир ва хаёлангизлиги, кўпинча вазн, қофия, ташбих, истиора, мажоз ва кинояларнинг кўлланишига боғлиқ бўлса-да, аммо лафзий сўз безаклари хам бадиий асарда гўзаллик ва маънавий рух бағишлаши хақиқатдан йироқ эмас.

Бадиий санъат нима? Оддий сўзнинг гўзаллик бағишловчи эстетик имкониятларини ошириш мақсадида маъно, лафз ва вазн жахатидан юз берадиган хар бир ўзгариш бадиий санъат деб аталади. Бошқача айтганда, сўзнинг оддий бир луғат даражасидан кенг маъноли сўз даражасига ва оддий товуш даражасидан мусиқийлик даражасига кўтарувчи хар бир ходиса - бадиий санъатдир. Санъатлар икки - лафзий ва маънавий қисмларга бўлинади, шунингдек, санъатлар мухсаноти лафзий ва мухсаноти маънавий деб хам юритилади. Лафзий санъат ё лафзий-бадиий, ўзининг мавзуига кўра сўз гўзаллигини шаклий ва лафзий томонларини ўрганади $(2,25$; 
2,76). Бизнинг бахсимиз ушбу мақолада лафзий бадиий санъат тури тажнис санъати доирасидадир.

Тажнис турлари. Тажнис, лафздошлик даражаси ва имлосига қараб томм ва ғайри томм қисмларига бўлинади. Тажниснинг томм қисмидаги жинсдош сўзлар туркуми ўзаро исм, феъл ва харф бўлиб мослашиб келганда, мутамосил ё мамосил тажнис дейилади ва агар хамжинс ишлатилган сўзларнинг бири фељл ва кейингиси исм бўлганда муставфо тажнис деб аталади. Ғайри томм тажнисда, ўхшама - мутажонис сўзларнинг хар тўрт шартидан бири (харфлар сони ва тури, тартиби, унли ва ундошга оидлиги, олдин ва кейин келиши) бўйича фарқланиб, ноқис ё мухарраф, лафзий, лохиқ, хаттий ё тасхиф, мукаррар, муштақ ё мулхиқ, зойид, мураккаб ва қалб тажнисларига бўлинади $(8,20-22)$.

Илми бадеъга оид манбаларда тажнис хақида етарли маълумотлар мавжуд. Масалан: Умар Родуёнининг “Таржумон улбалоға" асарида (XI аср) тажниснинг туурт тури (тажниси мутлақ, тажниси мураккаб, тажниси зойид, тажниси мураддад), Рашидуддин Ватвотнинг “Хадойиқ ус-сехр фи дақойиқ уш-шеьр” (XII аср), “Шамс Қайс Розийнинг “Ал-мўъжам фи маъойири ашъор ал-ажам” (12181233) хамда Шайх Ахмад Тарозийнинг "Фунун ул-балоға" (14361437) асарларида етти тури (тажниси томм, тажниси ноқис, тажниси зойид, тажниси мукаррар, тажниси мураккаб, тажниси мутарраф, тажниси хат) келтирилган. Тажнис хақидаги нисбатан кенгроқ маълумот Атоуллох Хусайнийнинг "Бадойиъ ус-саное” (XV acp) асарида берилган. Муаллиф дастлаб тажнисни икки катта гурухга ажратади:

1. Лафзий тажнис. Бу гурухга тажниснинг куйидаги беш тури киритилган: тажниси томм (тажниси тасрих), тажниси ноқис, тажниси музаййал, тажниси музореь, тажниси лохиқ.

2. Ғайри лафзий тажнис. Бу гурухга тажниси хаттий, тажниси мушавваш, тажниси бил-ишора кабилар киритилган.

Асосий қисм. Туркий мумтоз адабиётда тажнис кенг қўлланилган. Алишер Навоий ижодида тажниснинг олти тури (тажниси томм ёки мутлақ тажнис, тажниси зойид (орттирилган тажнис), тажниси музориъ, тажниси хат, тажниси мукаррар, тажниси мураккаб) кўп истифода этилганини кузатиш мумкин, - дейилади айрим манбаларда (“Алишер Навоий. Қомусий луғат”. Иккинчи жилд. - Тошкент: Sharq НМАК, 2016. 10 -11-б.). Аммо Навоий ижодида тажниснинг бошқа турлари хам учрайди. Бизнинг тадқиқотимиз натижасида шоирнинг "Ғаройиб ул-сиғар" девонидаги ғазалларда турли-туман ва бехисоб сўз безаклари сингари, тажниси қалб, иштиқоқ ва бошқалар кенг ва фаровон ишлатилган.

1. Тажниси томм ёки мутлақ тажнис. Шаклан бир хил бўлган икки хамжинс сўздан иборат мутаносиб сўзларнинг шакли, унли ва ундош харфлар сони, тузилиш тартиби, кўриниш таркиби (харакатлари ва харакатсизликлари)нинг бошқа бир сўзга ўхшаш тушиши, яъни маъно жахатидан фарқли бўлган - лафзан бир ва маъноси турлича тўлиқ шаклдошликка асосланган тажнис. Масалан:

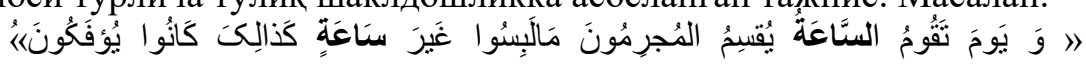

(Куръони карим, Рум сураси: 55-оят). Маъноси: Ва қиёмат бўладиган кунда, гунохкорлар бир соат кечиктирмасликка құасам ичадилар [бу дунёда хам] улар шу каби ёлгон гапиришардилар. 
Сурада дастлаб келган соат сўзи Қиёмат куни маъносини, иккинчи ўринда келган соат сўзи бир соат - 60 дақиқани англатади. Сўзларнинг шакли, тартиби, харфлари, харакатлари ва барча лафзий хусусиятлари бир-бирига мувофиқ ва мос келади.

Алишер Навоийдан:

Югурурлар хуар кирпигимга ортилиб бир қ̧атра ёш

Шугх ёшлардек ки уйинарлар чубуқ маркаб құилиб (“Ғаройиб уссиғар", 55-ғ.)

Юқоридаги байтда ёш сўзи икки марта тугал ва тўлиқ жинсдошлашиб келган. Демак, бу икки мутажонис сўз орасида тўлиқ тажнис бор, зеро икки бора ишлатилган ёш сўзи, лафзда бир хил бўлиб, маънода бошқача эканлиги кўринади. Яъни биринчи ёш сўзи ашк ё кўз ёш томчиси деган маънони англатса, иккинчи ёш сўзидан ёш йигит ё ўсмир, ўспирин деган маъно тушунилади.

Яна:

Закот ўлур эди юзунг жамоли нақдига мехр,

Тажаммул ахлива юздин бир ўлса эрди закот ("Ғаройиб уссиғар", 75-ғ.)

Байтда икки марта кўлланган тўлиқ жинсдош 103 сўзининг биринчиси маъноси чехра бўлса, иккинчи юз сўзи саноқни англатади.

Яна:

Уй бино айлаб ажсабтур элни мехмон айламак, 223-ғ.)

Улки бу уй ичра беш кун мехмоне беш эмас (“Ғаройиб ус-сиғар”,

Алишер Навоийнинг "Ғаройиб ус-сиғар" девонида тўлиқ тажнис кўлланган ғазалларни тартиб билан келтирамиз. Демак, пок сўзи 324ғазал таркибида; кўк сўзи 393-ғазал таркибида; ким сўзи 105- ва 215ғазаллар таркибида; мардум сўзи 515-ғазал таркибида; мехр сўзи 582ғазал таркибида; ёш сўзи 159- ғазал таркибида; юз сўзи 231-, 299, 572 , 609-, 610-, 628-ғазаллар таркибида кўлланилган.

2. Ноқис ё мухарраф тажнис. Жинсдошлашган сўзларнинг харфлари бир хил, харакат ё унлилари хар хил бўлган сўз санъатига ноқис тажнис дейилади $(12,2)$ Мисоллар:

Базми васлидин йироқ овзимда хумдек мухр эрур,

Тонг эмас қуонимва майдек мехр ўтидин тушса жуй ("Ғаройиб ус-сиғар", 25-ғ.).

Байтдаги мухр ва мехр сўзлари орасидаги бадиий боғлиқлик ноқис тажнисдир, чунки бу сўзлардаги харфлар бир хил, аммо маъно ва харакатлари хар хилдир. Яъни биринчи мухр сўзи тамға маъносини англатса, иккинчи мисрадаги мехр сўзида шавқ ва мухаббат маънолари ифодаланган. Хамда:

Туз булл угқтек гар тиларсен авж, ёким, эгридур,

Давр хар бир гучшадин бўвзива солиптур кериш ("Ғаройиб уссиғар", 258-ғ.).

Байт таркибидаги дур ва давр сўзлари шакл жахатидан бир-бири билан тўла ўхшаш (араб ёзувида кўриниши назарда тутилмоқда), аммо айтилиши жихатидан бир оз фарқли ва хар бири алохида маънони англатади. Масалан: биринчи дур сўзидан форсчадаги хаст деган тушунча кўзланган бўлса, кейинги давр сўзи замон/вақт маъносини англатади.

Девондаги ғазалларда хам ноқис тажнис кўлланилган, жумладан: давр - дур сўзи 345- ва 507-ғазаллар таркибида; умр - умар сўзи 528-ғазал таркибида учрайди. 
3. Тажниси лафз. Лафзий тажнисда жинсдош сўзларнинг ёзилиши хар хил, талаффузи бир-бирига яқин бўлиб келади. Лафз тажниси ислом доират ул-маъорифида муташобих тажнис деб қайд этилган; унда read (ўқимоқ) ва reed (най) маъносини англатувчи инглизча сўзлар хам мисол қилиб келтирилган. Нажафийнинг шу масалалар ўрганилган “Дурра" асарида ховн — хон ва хўрд - хурд каби сўзларни лафзий жунос деб киритилган, зеро ушбу сўзларнинг айтилиши яқин, деярли бир хил бўлиб, ёзилишида фарқи бор. Баъзилар нозира ва нозира сингари сўзларни хам лафзий жунос деб эътибор қаратганларки, аммо арабча алифбо билан ёзилганда фарқи сезилиб қолади $(11,55)$. Масалан:

Дема кўктин куёш кетмиш, фалакка тиралик етмиш,

Ул ой хижрида тор этмиш фалакни дуди афғоним (“Ғаройиб уссиғар", 403-ғ.).

Яна:

Ул пари куинглумда мехмон ўлмиш, ай жон воқиф ўл,

Ох утти дуд этмасун, захм ичра пайкон бўлмасун ("Ғаройиб уссиғар", 468-ғ.).

Ул ва ўл икки ўхшама мутажонис мустақил сўздирки, сўзларнинг унлилари бир-биридан фарқ қилади.

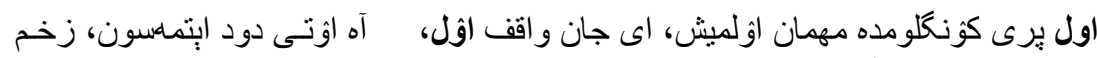

$$
\begin{aligned}
& \text { ايجــره يِيكان بؤلمهامون. }
\end{aligned}
$$

Девонда ушбу тажнисга оид байтлар қуйидаги ғазалларда келганини кузатамиз:

248-ғазал таркибидаги иш - эш сўзи ва 506-ғазал таркибида дур - дур сўзларини хамда 591-ғазал таркибидаги етти - этти сўзларини келтириш мумкин.

4. Хаттий ё тасхиф тажнис. Хаттий тажнисда сўзларнинг нуқталари қандай кўйилишидан қатьи назар (араб ёзувидаги сўзлар назарда тутилган), шакллари бир хил бўлган тажнис турига, хаттий тажнис ё мусхаф дейилади. (Араб ёзувидаги сўзларнинг фақат нуқталар орқали фарқланишига асосланган тажнис). Масалан:

Эй кўнгул, гар кимса ахқволим демас ёр олида,

Хотирим кимдин малул уллсун, кимим бор олида (“Ғаройиб уссиғар", 26-ғ.).

Юқоридага байтда ёр ва бор (بار ва بار ) сўзлари нуқталаридан қатъи назар бир хил шаклга эга. Икки сўз орасида ўхшашлик хусусияти боис тажниснинг бу тури хаттий тажнис деб аталади. Яна мисоллар келтирамиз ва айб - ғайб ва хол - хол сўзлари иштирокидаги байтларга эътибор қаратамиз:

Овзининг сирри манга маълум агар эрмас не айб,

Хеч кимга заррайи чун бермамиш хฺақ илми вайб ("Ғаройиб уссиғар", 51-ғ.).

Чун дедим: холинг била куз мардумининг хуоли бор,

Деди улким: хол деясен, нуқтасиз хуам хұол эрур ("Ғаройиб уссиғар", 195-ғ.).

Куйида шоирнинг ушбу девонидаги ғазалларда кўлланилган хаттий тажнислар кўлланилган ғазаллар хақида маълумот берамиз:

Они - оти сўзлари - ғазал таркибида; ит - ип сўзлари 63-ғазал таркибида; бўй — пуй сўзлари — 409-ғазал таркибида; бер - пир 
сўзлари 26-ғазал таркибида; бир - ер сўзлари 247-ғазал таркибида; пора - ёра сўзлари 403-, 599-ғазаллар таркибида; тоб - ноб сўзлари 194-ғазал таркибида; тош - бош сўзлари 8- ғазал таркибида; тано - яно ва ано - ато сўзлари 39-ғазал таркибида; чарх - харж сўзлари 94-ғазал таркибида; холи - холи сўзлари 176- ва 195ғазаллар таркибида; айб - ғайб сўзлари 51-ғазал таркибида; қайд қанд сўзлари 115-ғазал таркибида; ноз - ёз сўзлари 595-ғазал таркибида; не - бе сўзлари 45-ғазал таркибида; ёр - бор сўзлари 119-, 182-, 212-, 255-, 392-, 611-ғазаллар таркибида; ёра - пора сўзлари 64- ва 509-ғазаллар таркибида; ёшим - бошим сўзлари 396-, 568-, 619-ғазаллар таркибида; ют - тут сўзлари 415-ғазал таркибида; ютуб - тутуб сўзлари 53- ғазал таркибида; юрай - турай сўзлари 617-ғазал таркибида; ер - бер сўзлари 497-ғазал таркибида; ёр — боз сўзлари 274-ғазал таркибида; пора - ёра сўзлари 403-ғазал таркибида; юз - нур сўзлари 442-ғазал таркибида хаттий тажнис бўлиб келган.

5. Тажниси зойид (Орттирилган тажнис). Шаклан яқин сўзларнинг бирида бир- икки харфнинг ортиқча бўлишига асосланган тажнис. Масалан: озор - зор (1). Жинсдош ёки лафздош сўзларнинг олдида, ўртасида ва сўнгида бир ё икки харф орттирилгантда жунос зойид дейилади. Масалан: суд - хасуд, махрам - мухтарам, анжуман - анжум. Тартиб билан $\mathbf{x}-\mathbf{T}-\mathbf{н}$ харфлари зойид келтирилган (4). Шунингдек, биринчи мутажонис сўздан иккинчиси бир ё неча харф ортиқча бўлиб келса, бу — зойид тажнисдир. Демак, сўз таркибидаги орттирилган зойид товуш, сўзнинг олди, ўртаси ва сўнгида хам келиши мумкин $(9,3)$.

Эронлик олим Сирус Шамисо тажниси зойид хақида фикр билдириб, унинг уч турини таъкидлайди ва улар “орттирилган харфларнинг урни ва сонига қараб, мухталиф ул-аввал (жуноси мазид), мухталиф ул-васат (жуноси васат), ва мухталиф ул-охир (жуноси музайял) деб номланган” $(11,66-69)$. Бизнингча, мухталиф сўзининг ушбу ўринда ишлатилиши деярли мослашиб келмаган, чунки тажниси зойидда айнан кўлланилган мутажонис сўзларининг харфлари бири бошқасидан бир ё иккитага ошиб келади ва ушбу ортиқча келган харфлар сўзнинг уч жойида келиши мумкин; шунга биноан мухталиф сўзининг ўрнида мазид атамаси берилиб, мазид улаввал, мазид ул-васат ва мазид ул-охир бирикмалари кўлланилганда маъқул бўларди. Тажниси зойидни Шамисодан бошқа хеч ким бундай тасниф қилмаган.

Алишер Навоий ғазалларидан тажниснинг ушбу турига мисоллар келтирамиз:

Ғунчанг анфоси насими заврақи жон құасдива

Еткурур хуар дам адам дарёсидин мавжи фано ("Ғаройиб уссиғар", 37-ғ.).

Байтдаги дам ва адам сўзлари ўртасида зойид тажнис бор, чунки дам сўзига нисбатан адам сўзининг аввалида бир харф - айн харфи орттирилган.

Жому май гар буйладур, ул жом учун құилмоқ бўлур,

Юз жахуон хуар дам нисор, ул май учун минг ж⿻н фидо ("Ғаройиб ус-сиғар", 1-ғ.).

Жахон сўзининг хо товуши жон сўзига нисбатан ортиқ, шунга биноан зойид тажнис деб аталади.

Анжуман ахли юзин гулгун қ̧илоли май била, 
Мехрдин топкунча анжум гуллари бир-бир шикаст ("Ғаройиб уссиғар", 77-ғ.).

Анжуман ва анжум сўзлари ўзаро харфларга нисбатан мутажонис бўлган, аммо анжуман сўзининг сўнгида нун харфи зойид (ортиқ) келган, шунга асосан, орттирилган тажнис дейилади.

Тасбехни май рахьни қил, хқар донава майл этмагил,

Гар истасанг куинглунг кушин сайд этмагай бу домгах ("Ғаройиб ус-сиғар", 557-ғ.).

Жон бериб олдим жунуну ишқ то бўлдум фано,

Аллох-аллох ул не хуш савдо, бу не хуш суд эрур (“Ғаройиб уссиғар", 136-ғ.).

Қошу қุаду зулфидин пайваста то наълу алиф,

Танда кестим, ноладин озурда жисми нол эрур ("Ғаройиб уссиғар", 195-ғ.).

Шавк̧ аро гах мйядин бўлмоқ керак андоқ̧ ки мйуй,

Хижр аро гах ноладин андоқ ки нол уллмоқ керак ("Ғаройиб уссиғар", 333-ғ.).

Девондаги ғазалларда кўлланилган зойид тажнисга оид маълумотларни келтирамиз: учун - учкун сўзлари 443- ғазал таркибида; жахон - жон сўзлари 166-ғазал таркибида; халос - хос сўзлари 271-ғазал таркибида; хам - хасм сўзлари 540-ғазал таркибида; хуш - ваш сўзлари 256-ғазал таркибида; диёр - ёр сўзлари 204-ғазал таркибида; ситез - тез сўзлари 210- ғазал таркибида; суд - савдо сўзлари 123-, 169-, 438-, 631-ғазаллар таркибида; сайр - сар сўзлари 7-ғазал таркибида; шахр - шах сўзлари 265-ғазал таркибида; олим - алам сўзлари 464-ғазал таркибида; қадам - дам сўзлари 286- ғазал таркибида; мойил хамойил сўзлари 382-ғазал таркибида; махрам - мухтарам сўзлари 501-ғазал таркибида; мўя - мўй сўзлари 333-ғазал таркибида; май майл сўзлари 557-ғазал таркибида; нолах - нол сўзлари 195-ғазал таркибида; нихон - пинхон сўзлари 277- ва 392-ғазаллар таркибида; ёмон - амон сўзлари 443-ғазал таркибида; махрум - махрам сўзлари 6-ғазал таркибида; Жом - жам сўзлари 16- ва 105-ғазаллар таркибида; таб - тоб сўзлари 194- ғазал таркибида; ноз - ниёз сўзлари 201- ғазал таркибида; бас - бўс сўзлари 328 ғазал таркибида; тараф - турфа сўзлари 12-ғазал таркибида; давр - дав сўзлари 29ғазал таркибида; анжуман - анжум сўзлари 77- ғазал таркибида; шах - шахр сўзлари 265-ғазал таркибида; илс - уйла сўзлари 83ғазал таркибида; рух — мажрух сўзлари 93-ғазал таркибида; куёш ёш сўзлари 245- ғазал таркибида; ором - дилором сўзлари 84-ғазал таркибида; уй - уйла сўзлари 166-ғазал таркибида; ғаниймат ғаний сўзлари 207-ғазал таркибида; давр - даврон сўзлари 207ғазал таркибида; муғанний - мағоний сўзлари 225-ғазал таркибида; pyx - мажрух сўзлари 102-ғазал таркибида; хаёлий - хилий сўзлари 108-ғазал таркибида; ком - ноком сўзлари 110-ғазал таркибида; кўк - кавкаб сўзлари 162-ғазал таркибида; ўтун - ўт сўзлари 162- ва 204-ғазал таркибида; хол - хаёл сўзлари 171-ғазал таркибида; учун-чун сўзлари 172-ғазал таркибида; гўр - гўри сўзлари 172-ғазал таркибида; ай - вой сўзлари 175-ғазал таркибида; хамдам - дам сўзлари 200-ғазал таркибида; ёр - ё сўзлари 200- 
ғазал таркибида; била - биласиз сўзлари 203-ғазал таркибида; диёр — ёр сўзлари 204-ғазал таркибида; хумор - хор сўзлари 204-ғазал таркибида; замона - замон сўзлари 215-ғазал таркибида; бахр бар сўзлари 216-ғазал таркибида истифода этилган.

6. Кўшма ё мураккаб тажнис. Тажниснинг ушбу турида икки мутажонис сўз мураккаблашиб бириккан холда келади, мутажонис бўлиб келган сўзлар кунт билан ўқишни талаб қилади. Ўқилишидан тушуниладиган сўзлардан бирининг содда, иккинчисининг мураккаб бўлиши боис у мураккаб тажнис дейилади; яъни “шаклдош сўзларнинг бири - яхлит бир сўздан, иккинчиси - икки сўздан иборат бўлиши орқали вужудга келадиган тажнис. Масалан :

Чарх тортиб ханжари хуижрон бу тун,

Куймади бир зарра бавримни бутун.

Тунга бориб бизни бехуол айладинг,

Не балолив ёр эмиш ёраб бу тун (“Бадойиъ ул-васат”, 6-туюқ).

Гарчи ушбу кўшма мутажонис сўзлар туюқ шеьри жанрининг талабига кўра қофиядош бўлиб келгани ва унинг пухта кўлланилгани яққол сезилса-да, аммо тажнис санъати сингари сўз ўйинини хосил қилиб, турли ўринларда келмаган. Мураккаб тажнисларга мисоллар келтирамиз:

Хар лабинг ўлганни тиргузмакда, жоно, жон эрур,

Бу жахуатдин бир-бириси бирла жоножон эрур ("Ғаройиб уссиғар", 168-ғ.).

Юқоридаги байтда жоно, жон ва жоножон сўзлари орасида мураккаб тажнис борлиги сезилади. Демак, ушбу бирикмада сўзлар орасидаги сўз уйини диққатни тортади. Яъни биринчи мутажонис сўзнинг онломи ундов фељли билан мақсад томон борганда, иккинчи кўшма сўзнинг маъносида ўта самимийлик ифодаланади:

Йўқ Навоий бедил оромий вам ичра, эй рафик,

Холини зинхорким, куррсанг дилоромимzа айт (“Ғаройиб уссиғар", 84-ғ.).

7. Лохиқ тажнис: икки жинсдош ва лафздош сўз таркибидаги харфларнинг биттаси фарқли ё алохида махражли бўлса, лохиқ тажнис дейилади. Масалан: арш ва фарш икки мутажонис сўздан иборатки, икковининг бошланишидаги товуш бир-биридан фарк қилади. Аммо сўзни ўзгартириб келаётдиган харф сўзнинг биринчи ё иккинчи харфига тўғри келса, тажниси музориъ ва жинсдош сўзларнинг сўнгги товуши ўзгариб келганда, тажниси мутарраф деб юритилади.

Рафиқинг тойир андоққким Сулаймон олида худхуд,

Буроқинг сойири анжум шохи устида сипихр осо .

Юқоридаги байтда тойир ва сойир сўзлари орасида лохик музориъ тажнис бор, чунки хамжинс сўзларниннг биринчи харфлари мухталиф келган, у хам бўлса, то ва син харфларидир. Шунингдек, очар - қочар, мен - сен, нўш - неш, рух - рох, уй - ул сўзлари орасида лохиқ тажнис мавжуд, зеро хар икки хамжинс сўзнинг биринчи ё иккинчи ё учинчи харфлари ўзгариб келган.

Шах юруб олам очар, дарвеш оламдин қочар,

Хам уззунг инсоф бергил ким бу не нисбат анго ("Ғаройиб уссиғар", 8-ғ.).

Мену муз дайри аро мувбача бошида вулу, 
Сену зухуд ахли била масжиду мехроб тугла ("Ғаройиб ус-сиғар", 32-ғ.).

Дема санчиб неши хуижрон еткурди нуиши васол,

Чун бу нуишунг уллтуруб ул неш хуам санчилди тут ("Ғаройиб уссиғар", 70-ғ.).

Хаётбахи лабинг рух эмиштук эй, соқцй,

Магарки вовини эълол этиб қилибсен рох (“Ғаройиб ус-сиғар”, $103-$ ғ.).

Дахр судидин тамаъ узким, зиёне беш эмас,

Умрни тутқил ваниматким, замоне беш эмас ("Гаройиб уссиғар", 223-ғ.).

Уй бино айлаб ажабтур элни мехмон айламак,

Улки бу уй ичра беш кун мехмоне беш эмас (“Ғаройиб ус-сиғар", 223-ғ.).

Девондаги ғазалларда лохиқ тажниси қайси сўзлар ёрдамида кўлланганини келтирамиз:

Об - тоб сўзлари 42-ғазал таркибида; очар - сочар сўзлари 157- ғазал, таркибида; ошуфта — олуфта сўзлари 163-ғазал таркибида; ох — гох сўзлари 149-ғазал таркибида; ойим - ройим сўзлари 540-ғазал таркибида; адо - фидо сўзлари 436-ғазал таркибида; аро - қаро сўзлари 218-ғазал таркибида; амон - замон сўзлари 412-ғазал таркибида; ўқ - ўт сўлари 405- ва 610-ғазаллар таркибида; эмас - эман сўзлари 376-ғазал таркибида; бош - боқ сўзлари 464-ғазал таркибида; боғ - чоғ сўзлари 555-ғазал таркибида; боғ - доғ сўзлари 297 - ғазал таркибида; бой - ой сўзлари 630 ғазал таркибида; бас — хас сўзлари 640-ғазал таркибида; баст - даст сўзлари 46-ғазал таркибида; бўй - хуй сўзлари 409-ғазал таркибида; бермас - эрмас сўлари 45-ғазал таркибида; бил - бир сўзлари 501ғазал таркибида; пак - хок сўлари 329-ғазал таркибида; пари дари сўзлари 576-ғазал таркибида; пас — хас сўзлари 230-ғазал таркибида; пуя - поя сўзлари 290-ғазал таркибида; тош - тиш сўзлари 182-ғазал таркибида; том - тош сўзлари 162-ғазал таркибида; тун - кун сўзлари 91-, 190-, 295-, 580-, 582-ғазаллар таркибида; тенг - кенг сўзилари 344-ғазал таркибида; жом - жон сўзлсри 7-ғазал таркибида; жоним - ёним сўзлари 525-ғазал таркибида; жафо — вафо сўзлари 143-, 183-, 408-, 448-, 506-, 562-, 574-ғазаллар таркибида; хол - сол сўзлари 433-ғазал таркибида; ханж - ланж сўзлари 92-ғазал таркибида; ханд - қанд сўзлари 135ва 539-ғазаллар таркибида; доғ — чоғ сўлари 147-ғазал таркибида; доғи - ёғи сўзлсри 555-ғазал таркибида; дом - ром сўзлари 428ғазал таркибида; даф - каф сўзлари 308-ғазал таркибида; давр дайр сўзлари 308-ғазал таркибида; дахр - захр сўзлари 428-ғазал таркибида; раф - наф сўзлари 506-ғазал таркибида; зиён - замон сўзлари 223-ғазал таркибида; солғой - қолғой сўзлаеи 62-ғазал таркибида; сар - зар сўзлари 80 -ғазал таркибида; сам - дам сўзлари 200-ғазал таркибида; шом - жом сўзлари 78-ғазал таркибида; сафир - сарир сўзлари 193-ғазал таркибида; ғам - кам сўзлари 200-ғазал таркибида; ғам - нам сўзлари 200-ғазал таркибида; ғам - хам 
сўзлари 222-ғазал таркибида; фош - тош сўзлари 246-ғазал таркибида; фош - ёш сўзлари 259-ғазал таркибида; фалак - малак сўзлари 39-ғазал таркибида; фано - лано сўзлари 39-ғазал таркибида; қош - қон сўзлари 34-ғазал таркибида; қолиб - солиб сўзлари 54-ғазал таркибида; қон - жон сўзлари 96- ва 170-ғазаллар таркибида; кон - хон сўзлари 227-ғазал таркибида; қон - кон сўзлари 583-ғазал таркибида; қадам - адам сўзлари 34-ғазал таркибида; каро - яро сўзлари 218-ғазал таркибида; куш - хуш сўзлари 355-ғазал таркибида; қиш - киш сўзлари 288-ғазал таркибида; килур - билур сўзлари 189-ғазал таркибида; ком - дом сўзлари 428-ғазал таркибида; камол - жамол сўзлари 101-ғазал таркибида; этмиш - етмиш сўзлари 403-ғазал таркибида; киши иши сўзлари 102-ғазал таркибида; кин - чин сўзлари 54-ғазал таркибида; гар - хар сўзлари 248-ғазал таркибида; ганж - ранж сўзлари 92-ғазал таркибида; лола - жола сўзлари 440- ва 440ғазаллар таркибида; лола — нола сўзлари 555-ғазал таркибида; мохим - охим сўзлари 423-ғазал таркибида; маст - даст сўзлари 77-ғазал таркибида; мў — сў сўзлари 510-ғазал таркибида; май — най сўзлари 581-ғазал таркибида; нам - дам сўзлари 160-ғазал таркибида; нўш - неш сўзлари 70-ғазал таркибида; нихон - жахон сўзлари 214-ғазал таркибида; вах - рах сўзлари 403-ғазал таркибида; хавас - хаво сўзлари 226-ғазал таркибида; ёд - шод сўзлари 126-, 353-, 568-ғазаллар таркибида; ёш кош сўзлари 268-ғазал таркибида; етти - иетти сўзлари 591-ғазал таркибида; Ўзга - С̆̈зга сўзлари 209-ғазал таркибида; 103 - ёз ва тез — хез сўзлари 210-ғазаллар таркибида; васл - фасл сўзлари 210-ғазал таркибида; қаро - яро сўзлари 218-ғазал таркибида; эл - тил сўзлари 220-ғазал таркибида; ғам - хам сўзлари 222-ғазал таркибида; уй - ул сўзлари 223-ғазал таркибида; кир - ким сўзлари 223-ғазал таркибида; иш - эл сўзлари 223-ғазал таркибида; таркибида; шом - жом сўзлари 77ғазал таркибида; санга - манга сўзлари 225-ғазал таркибида; олим - холим сўзлари 158-ғазал таркибида; тош - теш сўзлари 182-ғазал таркибида; сам - дам сўзлари 200-ғазал таркибида; ун - ул сўзлари 227-ғазал таркибида; бир - биз сўзлари 228-ғазал таркибида; кас бас сўзлари 235-ғазал таркибида учрайди.

8. Иштиқоқ тажнис: Иштиқоқ луғатларда “сўздан сўзни ажратмоқ” деган маънода изохланган. Адабий истилох сифатида байт ёки жумла таркибидаги ўзакдош сўзларни махорат билан кўллаш санъатига иштиқоқ тажниси деб таъриф берилади. Алишер Навоий ушбу бадиий санъат ёрдамида гўзал ғазаллар битган.

Зихуи васолингга толиб тутуб ўзин матлуб,

Мухฺаббатдин отингни хүабиб атаб махбуб ("Ғаройиб уссиғар", 40-ғ.).

Байтдаги толиб - матлуб хамда хабиб - махбуб жуфтлигидаги сўзларнинг негизи битта бўлганлиги учун иштиқоқ тажниси деб аталади, зеро ушбу сўзларнинг асоси - илдизи талаб ва хуб сўзларидир. Демак, ана шу икки гурух сўзлар бир масдардан ажралганлиги учун, иштиқоқ тажниси дейилади.

Халол бўлди хароботи ишқ ахқлва май,

Тутарбиз ахли вараъ кимки они тутса мубох (“Ғаройиб уссиғар", 103-ғ.).

Толиб улким топмасанг дови бу баским, айламас, 
Бир нафас вофил сени матлуб ёдидин талаб (“Ғаройиб уссиғар", 45-ғ.).

Юқоридаги байтда толиб - матлуб суузлари орасида иштиқоқ тажнис бор, чунки толиб ва матлуб, талаб сўзидан муштақ бўлган.

Ғарқ ўлай май бахри ичра рост ўл гоятқача,

Ким, солиб бугзум аро чеккай ажсал куллоби шаст ("Ғаройиб уссиғар", 76-ғ.).

Мехр таркин құилибон паст, фалак рахшидин ўтти,

Аллох-аллох, не бу не рокибдуруру, вах, бу не маркаб ("Ғаройиб ус-сиғар", 46-ғ.).

9. Шибхи иштиқоқ. Жинсдош сўзларнинг ўхшашлик томонлари бир негизли бўлиб тушунилганда, мутажонис сўзлар шибхи иштиқоқ деб англашилади. Масалан, анжуман ва анжум сўзларининг негизи ягонадек туюлади, аммо хар бири алохида мустақил сўз сифатида алохида маъно англатади.

Анжуман ахли юзин гулгун қилоли май била,

Мехрдин топкунча анжум гуллари бир-бир шикаст ("Ғаройиб уссиғар", 77-ғ.).

Ғазалларда кўлланилган шибхи иштиқоқ тажнисга оид мисолларни девондаги ғазаллар рақами бўйича келтирамиз:

Бало - билол сўзлари, 51-ғазал таркибида; сахбо - сухайб сўзлари, 51-ғазал таркибида; шабоб - шайб сўзлари 51-ғазал таркибида; ваъда — ваъийд сўзлари, 127-ғазал таркибида; савдо суд сўзлари 169-ғазал таркибида; хол - хаёл сўзлари 171-ғазал таркибида; мақбул - иқбол сўзлари, 195-ғазал таркибида; ноз ниёз сўзлари 201-ғазал таркибида; ром - ором сўзлари 224-ғазал таркибида; насим - нисон сўзлари 207-ғазал таркибида; ғанимат ғаний .

10. Тажниси мукаррар ё муздавиж. Шаклан бир-бирига яқин икки сўзнинг мисра охирида ёнма-ён келишига асосланган тажнис. Бунда тажниснинг хар бир тури келтирилган бўлиши мумкин. Масалан:

Ишқ эрур андоқ мураббийким, келур эткач асар, 158-г.).

Булбул уллвай очса юз бир сарви гул рухсор-сор (Бадойиъ ул-васат

Ай кўнгул ёрсиз сенга не бор, бор

Қайда ким ул зулфи анбар бор, бор

Чек жафоу жавр нози борни

Бир кун уллгой ким дегайлар бор, бор (Мавлоно Лутфи Хиравий, 4туюқ).

Юқоридаги байтларда зойид, тўлиқ тажнис мисралар сўнгида кўлланилган.

Изох. “Ғаройиб ус-сиғар” девонидаги ғазалларда мукаррар тажнис кўлланилган байтлар учрамади.

11. Қалб. Қалб тажнисининг белги ё мохияти шундаки, икки мутажонис сўздан бирининг харфлари, тескари тартибда мос келади; ушбу санъат икки турга ажралиб, биринчиси қалби кулл ё комил ва иккинчиси қалби баъз ё мустави номи билан юритилади. Жумладан:

a) хамжинс сўзларнинг харфлари тартиб юзасидан тескари ўқилганда, қалби кулл дейлади; масалан:

Хаётбахи эса ул хур аксидин бода, 
Махуалли хайрат эмас, хур аксин дур рух (Ғаройиб ус-сиғар, 102ғ.);

б) икки хамжинс сўзнинг харфлари, бир-бирига тартибсиз равишда ўзгартирилган холда кўлланилса, қалби баъз деб аталади;

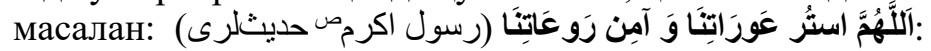

Ёки:

Қаноатнинг далилин инзиво қ̧илдинг яна бир хฺам,

Далил ушбу ки қониъ хқарфидин хал айладинг анқо (Ғаройиб уссиғар, 2-ғ.)

Хуш улки, ёр фироқию ё кугнгул вамидин

Тамом умрида бир лахза эрди мотамсиз (Ғаройиб ус-сиғар, 200ғ.).

Омуруб хуаддин Навоий хам ниёзу ажзини,

Ёр истигнову нози хฺар неча хฺаддин ошиб (Ғаройиб ус-сиғар, 61ғ.)

Изох. Тажниси қалбда, агар икки хамжинс сўздан бири, байтнинг бошида ва иккинчиси байтнинг охирида келтирилса, уни қалби мужаннах деб хам атайдилар,

Изоху. Мужаннах турга оид шеръий намуна, "Ғаройиб ус-сиғар" девонидаги ғазалларда учрамади.

Хулоса. Бадиий жихатдан мукаммал бўлган Алишер Навоий ғазалларида бошқа шеьрий санъатлар каби тажниснинг ўрни мухим. Шоир ўзининг фалсафий-ирфоний, маърифий ғояларини, ўз рухиятини ифодалашда, ишқнинг нозик қирраларини тасвирлашда ушбу лафзий санъатнинг ўнлаб турларидан фойдаланди ва ғазал жанрининг юксак мақомга кўтарилишида ушбу шеърий санъатнинг вазифаларини кўп жихатдан белгилаб берди.

\section{Фойдаланилган адабиётлар}

1. Алишер Навоий. Қомусий луғат. Иккинчи жилд. - Тошкент: SHARQ HMAK, 2016. — 480 б.

2. Аминий Мухаммадкозим. Адабий фанлар (бадий ва баён қисми). - Маймана: Бангох чоп шамол:Нашрияйи озоди Маймана, 1390 хижр. -180 б.

3. Ахмад Нажод Комил. Фунуни адабий. - Техрон: Интишороти Поё, 1382-хижр. - 162 б.

4. Ишонч Зикруллах, Мухаммад Олим Кўхкан. Ўзбек адабиёти фарханги. - Форёб: Форёб давлат матбаъаси: Амир Алишер Навоий Фарханги анжумани нашриёти, 1374 хижр. - 370 б.

5. Калимоти Куръони карим. - Кум: Usva. 1388 хижр. 800 б.

6. Навоий Низомуддин. Ғаройиб ус-сиғар. Иккинчи жилд, Moliziyo: Global partners., 2008-милодий. — 479 c.

7. Олтой Нуруллах. Ўзбек тили сўзлиги. - Moliziyo: Global partners, 2007. - 420 б.

8. Ранжбар, Ахмад. Бадиий. - Техрон: Асотир,1385 хижр. - 139 б.

9. Санойи Ғазнавий, Мухаммадакбар. Гулистони латофат. Биринчи нашр. - Пешовар: Майван интишороти. 1382 хижр. -190 б. 
10.Хуросоний Мухаммадхорун. Бадиий ва баён. - Кобул: Интишороти Обид ва интишороти Мухаммад Рафиқ. 1394 хижр. 2116.

11.Шамисо Сирус. Нигохи тозайи ба бадиий. Ўн тўртинчи нашр. Техрон: Интишороти Фирдавс, 1383 хижр. - 211 с.

12.Хафизий Жавзжоний, Мухаммад Яхё. Адабий фанлар.

Жавзжон: Захируддин Мухаммад Бобур анжумани нашриёти, 1378 хижр. - 162 б.

\section{References}

1. Alisher Navoi, Komusii luzat (Encyclopedic dictionary), Second volume, Tashkent: Sharq NMAK, 2016, 800 p.

2. Aminiy Mukhammadkozim, Adabii fanlar (badii va baen қ̧ismi) (Literary Sciences (part of the science fiction and statement)), Maymana: Bangoh published wind: Publishing House Ozodi Maymana, 1390 hijr, 180 p.

3. Ahmed Nacad Kamil, Fununi adabii (Literary science), Tehran: Intisharat Paya, 1382 hijr, $162 \mathrm{p}$.

4. Ishonch Zikrullah, Muhammad Alim Kohkan, Uzbek adabieti farx̧angi (Dictionary of Uzbek literature), For work: state printing house for work: Alisher Navoiy Farhangi conference publishing house. 1374 hijr, 370 p.

5. Kalimoti Kur"oni karim (The Holy Quran), Qum: Usva. 1388 hijr, 800 p.

6. Navoi Nizamuddin, Faroiib us-sizar (Miracles of childhood), Second volume, Moliziyo: Global Partners, 2008, 479 p.

7. Oltoy Nurullah, Uzbek tili syzzligi (Uzbek language vocabulary), Moliziyo: Global Partners, 2007, 420 p.

8. Ranjbar, Ahmed, Badiii (In the science of artistry), Tehran: Asotir, 1385 hijr,139 p.

9. Sanoyi Gaznavi Muhammadakbar, Gulistoni latofat (Beautiful flower garden), First edition, Peshavar: Intisharati Mayvan. 1382 hijr, 90 p.

10. Xurosoniy Muhammadhorun, Badiii va baen (Fiction and statement), Kabul: Intisharati Abid and Intisharati Muhammad Rafiq. 1394 hijr, 211 p. 11. Shamiso Sirus, Nigoxy tozaii ba badiii (Be artistic in the charm of your eyes), The Fourteenth pressure, Tehran: Intisharat Firdavs, 1383 hijr, 211 p.

12. Hafiziy Javzjani, Muhammad Yahya, Adabii fanlar (Literary Sciences), Javzjan: Zahiruddin Muhammad Babur conference publishing house, 1378hijr, $162 \mathrm{p}$. 